\section{то ино арингология}

М еж у ународен бюле
1, Year 2019

Volume 15

ISSN 1312-6997

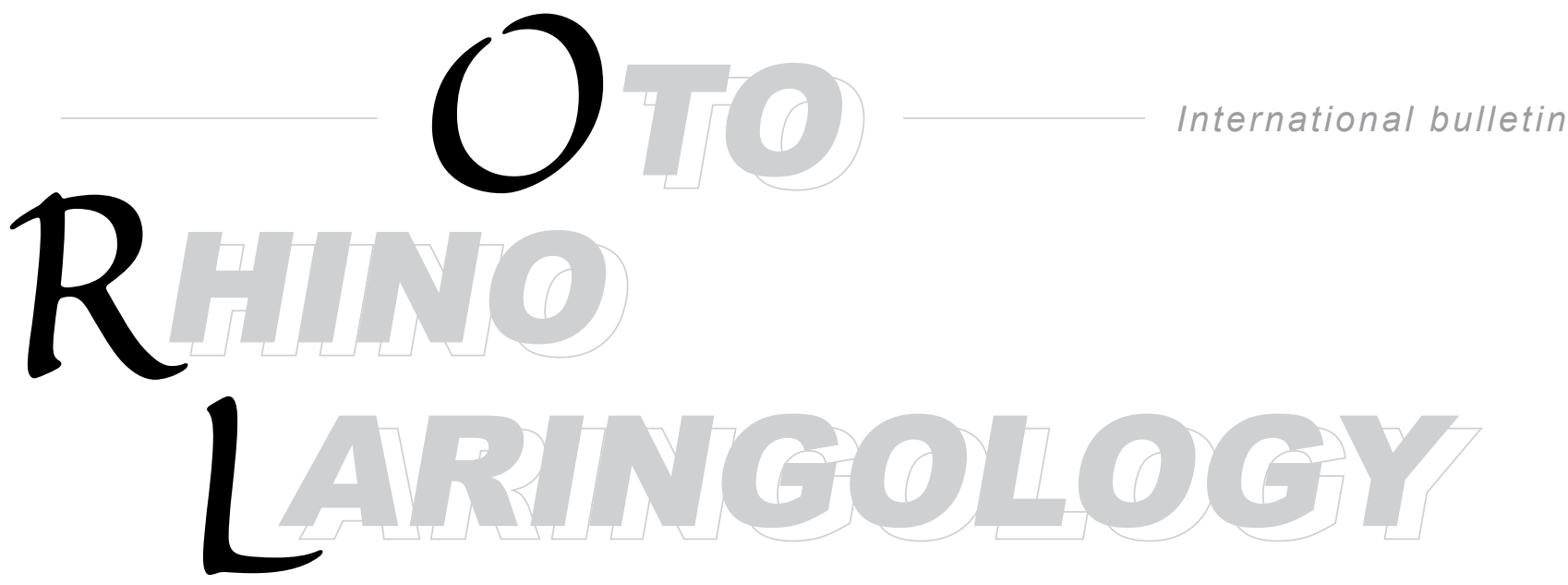

\section{Editor in Chief}

Mario Milkov (Bulgaria)

\section{Vice Editor in Chief}

R. Benchev (Bulgaria)

\section{Associate Editors}

K. Jambazov (Bulgaria)

D. Popova (Bulgaria)

V. Tzvetkov (Bulgaria)

I. Tzenev (Bulgaria)

\section{Associate Editors}

Europe:

C. Uzun (Turkey)

K. Hörmann (Germany)

Midle East

D. Fliss (Israel)

\section{North America}

E. Myers (USA)

\section{South America}

S. Da Costa (Brazil)

\section{Africa}

H. Negm (Egypt)

\section{Asia}

V. Honnurappa (India)

\section{International board}

A. Candela (Spain)

A. Desai (India)

Al. Rainov (Bulgaria)

A. Baumgartner (Austria)

A. Kuzarov (Bulgaria)

A. Neagos (Romania)

A. Varini (Italy)

A. S. Vieira (Portugal)

B. Hirsh (USA)

C. Batman (Turkey)

C. Cingi (Turkey)

C. Sarafoleanu (Romania)

D. Doskov (Bulgaria)

D. Konov (Bulgaria)

D. Marev (Bulgaria)

D. Pazardjcliev (Bulgaria)

D. Vicheva (Bulgaria)

E. Ferecidis (Greece)

E. M. Badr (Egypt)

E. Zenev (Germany)

F. Piazza (Italy)

F. Trabalzini (Italy)

G. Anastasopoulos (Greece)

G. Edrev (Bulgaria)

G. Georgiev (Bulgaria)

G. Iliev (Bulgaria)

G. M. O'Donoghue (England)

G. Marinov (Bulgaria)

G. Sprinzl (Austria)

H. Diab (Russia)

H. Frengov (Bulgaria)

H. Kaddour (England)

H. Skarżyński (Poland)

Hr. Zlatanov (Bulgaria)

I. Chalakov (Bulgaria)
I. Hizalan (Turkey)

I. Tzolov (Bulgaria)

I. Zlatanov (Bulgaria)

I. Yovchev (Bulgaria)

J. Dornhoffer (USA)

J. Helms (Germany)

J. Magnan (France)

J. P. Shah (USA)

J. Rangachev (Bulgaria)

J. Sade (Israel)

K. Diab (Rusia)

K. Görür (Turkey)

K. Ivanov (Bulgaria)

K. Park (Korea)

K. Popov (Bulgaria)

K. Schwager (Germany)

M. K. Adali (Odrin)

M. Bance (Canada)

M. Bernal-Sprekelsen (Spain)

M. Caversaccio (Switzerland)

M. Davidoff (Germany)

M. Dimova (Bulgaria)

M. Paparella (USA)

M. Profant (Slovakia)

M. Portmann (France)

M. Remacle (Luxembourg)

M. Stankovic (Serbia)

M. Sanna (Italy)

N. Ozgirgin (Turkey)

N. Sapunjiev (Bulgaria)

O. Borisenko (Ukraine)

O. Cruz (Brazil)

O. Stoianov (Bulgaria)

P. Dimov (Bulgaria)

P. H. Skarżyński (Poland)

P. Kabakchiev (Bulgaria)
P. Palma (Italy)

P. Ruev (Bulgaria)

P. Senn (Swizerland)

R. Grigore (Romania)

R. Guidoin (Canada)

R. Laszig (Germany)

R. Mlinski (Germany)

R. Sauce (USA)

R. Vincent (France)

R. Heusler (Switzerland)

S. Bersteanu (Romania)

S. Dazert (Germany)

S. Caldas (Brazil)

S. Karpischenko (Russia)

S. Konsulov (Bulgaria)

S. Kosyakov (Rusia)

S. Lolov (Bulgaria)

S. Peev (Bulgaria)

S. Triaridis (Greece)

S. R. Saeed (England)

S. Stoianov (Bulgaria)

S. Varbanova (Bulgaria)

S. Vasileva (Bulgaria)

Sp. Todorov (Bulgaria)

T. Avramov (Bulgaria)

T. Georgiev (Bulgaria)

T. Kalcioğlu (Turkey)

Tz. Tonchev (Bulgaira)

T. Shirov (Bulgaria)

V. Bertesteanu (Romania)

V. Budu (Romania)

V. Stoqnov (Bulgaria)

V. Svestarov (Bulgaria)

V. Panov (Bulgaria)

V. Pavlov (Bulgaria)

W. Grolman (Niederland) 
От месец февруари 2019 г. списание „Рефреративен бюлетин по ото-рино-ларингология“ е включено в Националния референтен списък на съвременни български научни издания с научно рецензиране под номер 621. В този списък се вписват издания, които прилагат предварително научно рецензиране на предложените за печат публикации и са регистрирани в Националната агенция за международни стандартни номера.

\section{Съдържание}

Guidelines for Authors

Surgical Treatment of Intratemporal Facial Nerve Tumors

Kh. M. Diab, N. A. Daikhes, I. I. Nazhmudinov, D. S. Kondratchikov, O. A. Pashchinina, A. S. Korobkin, O. S. Panina . . . . . . .5

Results of Surgical Treatment of Patients with Congenital Auditory Canal Atresia and Microtia

Kh. M. Diab, N. A. Daikhes, D. N. Nazaryan, D. S. Kondratchikov; O. A. Pashchinina, O. S. Panina $\ldots \ldots \ldots \ldots \ldots \ldots \ldots \ldots$

Investigation of Treatment with Periimplantitis with Antibiotic therapy

Dr. Radostina Vasileva MD, PHD, Assoc. Prof. Dr. Mario Milokov MD, PHD

Medical photography

Dr. Radostina Vasileva MD, PHD, Assoc. Prof. Dr. Mario Milokov MD, PHD, Prof. Dr. Rosen Kolarov, MD, PHD

VEMP - история и развитие на метода през годините

Калина Маджарова, Ана Бешкова

Грануломатоза на Wegener: човекът зад епонима

доц. д-р Добрин Паскалев

CV Diab Khassan Mohamad Ali

Карикатури проф. Недев

\begin{tabular}{|c|}
\hline $\begin{array}{c}\text { Correspondence, } \\
\text { subscription and advertising: }\end{array}$ \\
\hline $\begin{array}{l}9000 \text { Varna } \\
\text { Central Post, } \\
\text { box } 333\end{array}$ \\
\hline $\begin{array}{c}\text { Office: } \\
\text { 9002 Varna } \\
\text { St. „Gen. Kisselov“ } 27 \mathrm{fl} .1 \text {, } \\
\text { office } 2 \\
\text { tel./fax } 052 / 608546\end{array}$ \\
\hline $\begin{array}{c}\text { e-mail: } \\
\text { stenobg@gmail.com } \\
\text { www.stenobooks.com }\end{array}$ \\
\hline
\end{tabular}

Published by

Publishing House STENO

Copyright

(C) 2005-2019,

Publishing House STENO

All rights reserved.

No part of this publication may be reproduced or circulated without the written permission of the publisher. 


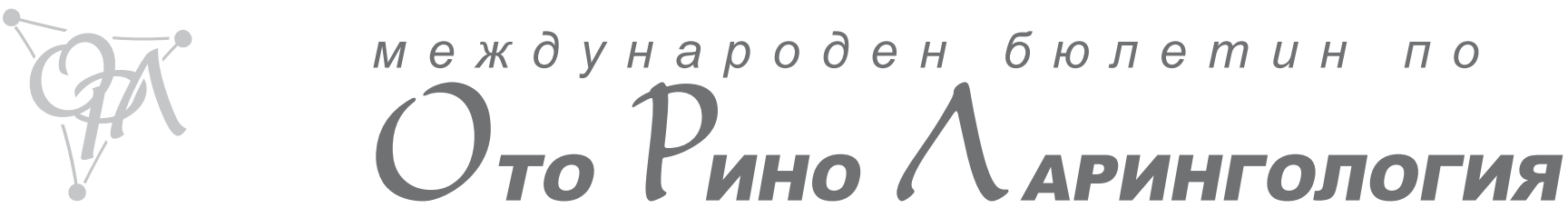

Година XV, Брой 1/2019 г.

\author{
Издание на \\ Издателска къща СТЕНО \\ Copyright \\ (C) 2005-2019 \\ Издателска къща СТЕНО \\ Всички права запазени. \\ Никаква част от това издание не \\ може да бъде препечатвана или \\ тиражирана без писмено \\ разрешение на издателя.
}

За кореспонденция, абонамент и реклама:

9000 Варна, Централна поща, П.к. 333

\section{Офис:} 9002 Варна

ул. „Ген. Киселов“ 27 , ет. 1, офис 2

тел./факс 052 / 608546

\section{e-mail:}

stenobg@yahoo.com www.stenobooks.com
Главен редактор: доц. Марио Милков Зам.-главен редактор: проф. Румен Бенчев

Асоциирани редактори: Румен Бенчев, Дияна Попова, Иван Ценев Председател на редакционната колегия проф. Д. Вичева

Редакционна колегия: П. Димов, К. Джамбазов, Т. Шиваров, Сп. Тодоров В. Цветков, Н. Сапунджиев, Г. Георгиев, В. Павлов, Г. Едрев, Д. Досков, И. Йовчев, И. Цолов, Г. Илиев, Д. Конов, П. Руев, Т. Аврамов, Хр. Френгов, Ст. Консулов, С. Върбанова, С. Стоянов, С. Лолов, В. Стоянов, А. Вълков, И. Чалъков, Ю. Рангачев, О. Стоянов, Д. Пазарджиклиев

Редактор на списанието и издателството: Димитринка Енева Рецензенти на броя: проф. Румен Бенчев, Р. Григоре 


\section{Guidelines for Authors}

These guidelines are in accordance with the „Uniform Requirements for Manuscripts submitted to Biomedical Journals" published in N Engl J Med 1997; 336: 309-315

The Bulgarian Journal Steno published original papers, editorials, short rapid communications, case reports and reviews concerned with aspects of general interest of the scientific basis, clinical features, and therapeutic approach of diseases. The journal is published quarterly and papers are accepted for publication both in English and Bulgarian languages. Manuscripts containing original material are accepted if neither the article nor any essential part of this has been or will be published or submitted elsewhere before. This restriction does not apply to abstracts or press reports published in connection with scientific meetings.

Submit an original manuscript with one set of original figures and two copies of the complete manuscript. Address all submissions to the Editor / M. Milkov, Journal Steno, street, №, Varna, Bulgaria.

The manuscripts should be on standard-sized A4 paper in doublespaced typewriting on one side of the paper only. Manuscripts must be prepared in accordance with the "Uniform Requirements for Manuscript submitted to Biomedical Journals". Manuscripts improperly prepared will be returned to the author without review. A separate covering letter signed by the authors must state that the data have not published elsewhere and identify the author to whom the correspondence must be submitted. All original manuscripts will be submitted to reviewers, known personalities in the field.

\section{Manuscript preparation}

Arrange manuscript as follows, each component (1-9) beginning on a separate page: (1) title page, (2) abstract, (3) introduction/ background, (4) material and methods, (5) results, (6) discussion, (7) references, (8) figure legends, (9) tables.

Place page number and first author's last name at top of each page.

Cite references, figures and tables consecutively as they appear in the text.

\section{(1) Title page}

Title should be concise and descriptive. The title page should include the name of the author with initials or distinguishing first name, and the name and address of the hospital or institution where the work was performed.

List grant support and other assistance.

List alphabetically abbreviations used and three to ten keywords. Provide name, complete address, telephone number and fax number of corresponding author.

Title page should include also a short (fewer than 45 characters) running head.

\section{(2) Abstract}

Provide on a separate page an abstract of not more than 250 words, consisting of four paragraphs, labeled: Background, Methods, Results and Conclusions. Do not use abbreviations, footnotes, or references. For original articles, if the paper is published in French, an English abstract should be added to the manuscript, and conversely.

\section{(3) Body of paper}

The paper must be conventionally structured in the following chapters: Introduction/

Background, Methods, Results, and Discussions. Each chapter must begin on separate pages. In Materials and Methods, the authors must give sufficient information to permit detailed evaluation and duplication of the work by other investigators. Ethical guidelines followed must be described.

Approval of institutional human research review committees or animal welfare committees should be cited. Outline statistical methods used. Identify drugs and chemicals used by generic name (if trademarks are mentioned, manufacturer name and city are given).

\section{(4) References}

Cite references in order of appearance in text using arabic numerals in parantheses. Cite personal communications and unpublished data directly in text without being numbered. Conform abbreviation to those used in Index Medicus. List of all authors when there are six or fewer; when there are seven or more, list the first three, than et al.

Examples:

\section{Original article}

23. Kimura K, Ohto M, Matsutani S, Furuse J, Hoshino K, Okuda $\mathrm{K}$. Relative frequencies of portosystemic pathways and renal shunt formation through the „posterior" gastric vein: portographic study in 460 patients. Hepatology 1990; 12: 725-728

$$
\text { Article in book: }
$$

21. Rousselot LM, Burchell AR. Splenic and arterial portography and hemodynamics in portal hypertension. In: Schiff L, ed. Diseases of the liver. Philadelphia: JB Lippincott, 1975: 368-423

\section{(5) Tables}

Tables must be typed and double-spaced, each on separate sheet. Number according to order of citation. Table number and title must appear above table, explanatory notes below.

\section{(6) Figure legends}

Figure legend must be typed and double-spaced. Numbered according to order of citation. Provide enough information to permit the interpretation of figure without reference to text.

\section{(7) Figures/llustrations}

Figures should be professionally designed. Submit one set of high-quality glossy photographs in a separate envelope. They will be submitted in actual-size, as they will be printed without enlargement or reduction. Identify each figure with first's author's last name, figure number in Arabic numerals and an arrow indicating the top on the backside on each figure marked with a soft pencil or on a self-adhesive label affixed to the back of each figure. Color ilustrations are accepted if they make an exceptional contribution. Authors will be required to subsidize the publication, if have colored figures at a cost of ? BNL per figure.

Case reports will only be accepted if of major merit and interest. Letters related with articles published in Steno or with topics of general interest are wellcomed.

Images in Clinical Medicine will publish the most interesting images in the field of clinical medicine addressed to the Editor. Corrections other than printer errors may be charged to the author.

\section{Peer-review procedure}

The Steno promotes evaluation of all the original papers by two or three independent (?) reviewers. The peer-review process is essential for ensuring the quality of the scientific information disseminated. The reviewers are asked to evaluate the manuscript by applying the same standards as for the international journals. The reviewers send their comments to the Editor. The Editor will inform the authors about the suggestions made by the referee and ask them to answer the questions and make the required corrections. The revised manuscript should be sent in no more than two months to the Editor. Revised manuscripts sent later will not be considered.

When the Editor receives the corrected version with all changes marked, accompanied by a letter with a point-by-point reply to the reviewers' comments, he sends those back to the same reviewer, who makes the final recommendation for acceptance or rejection of the manuscript. 